УДК 37.015.311-058.862

DOI: $\underline{10.35619 / \mathrm{iiu} . \mathrm{v} 2 \mathrm{i} 11.275}$

Лялюк Галина

кандидат психологічних наук, доцент, доцент кафедри психології діяльності в особливих умовах Львівського державного університету внутрішніх справ ORCID: 0000-0002-4819-6247,

м.Львів, Україна

e-mail: gala_psycholog@ukr.net

\title{
ТЕОРЕТИКО-МЕТОДОЛОГІЧНІ ПІДХОДИ ДО ВИХОВАННЯ ДІТЕЙ-СИРІТ У КОНТЕКСТІ ОСОБИСТІСНОЇ ПАРАДИГМИ
}

Анотація. У статті актуалізовано проблему виховання дітей-сиріт, які перебувають у державних закладах опіки. Наголошується, що у сучасних українських реаліях особливо гостро підсилюється актуальність забезпечення особистісного зростання дітей-сиріт в умовах трансформаційних змін. Обгрунтовано теоретико-методологічні основи виховання дітей-сиріт у контексті особистісної парадигми. Проаналізовано особистісний, особистіснодіяльнісний, гуманістичний, суб'єктний, синергетичний методологічні підходи до організації виховання дітей-сиріт у контексті особистісної парадигми.

Особистісна парадигма виховання дітей-сиріт не просто декларує, а утверджує дитину як найвищу цінність життя, передбачає визнання іiі індивідуальності, самобутності, самоцінності. Вихованець розглядається як особистість, яка сама може вибирати такий шлях освіти, який допоможе їй досягнути найкращих результатів. Особистісна парадигма виховання дітей-сиріт передбачає суб'єкт-суб'єктні відносини дитини та педагога. Сутнісною основою виховання виступають особистість дитини, визнання ії найвищою цінністю, орієнтація педагога на гуманні, демократичні принципи спільної з дитиною життєдіяльності, розуміння дитини як суб'єкта і мети виховання, усвідомлення виховання як соціально-особистісного феномена.

Гуманістична стратегія виховання дітей-сиріт у контексті особистісної парадигми визначає й гуманістичне навантаження технологічних засобів ії реалізації, характерними ознаками яких $є$ педагогічна допомога і підтримка; емпатійне ставлення до дитини; діалогічність, творчо-пошуковий характер, поєднання традиційності й інноваційності, гнучкий контроль і самоконтроль.

Ключові слова: діти-сироти, особистісна парадигма виховання, особистісний підхід, особистісно-діяльнісний підхід, гуманістичний підхід, суб'єкт-суб'єктний підхід, синергетичний підхід.

Постановка проблеми. Проблема виховання дітей-сиріт $є$ однією з найактуальніших проблем українського суспільства. У зв'язку із складними соціально-економічними, політичними умовами в нашій країні збільшується кількість дітей, що потребують опіки та підтримки з боку держави. Хоча держава визнала сім'ю пріоритетною формою влаштування дітей-сиріт, однак через нерозвиненість сімейних форм виховання наявна певна категорія дітей, які виховується у державних закладах опіки.

Визначення теоретичних основ розробки сучасних моделей виховання особистості дитини-сироти в умовах диверсифікації освітньо-виховного простору в Україні передбачає 
звернення до теоретико-методологічних засад педагогічної науки, зокрема парадигми виховання, яка виступає домінантою модернізації педагогічного процесу.

Перехід до нової особистісно-гуманної парадигми - провідна тенденція сучасної освіти й у цілому педагогічної свідомості суспільства наприкінці XX - початку XI століття. Нині в Україні провідним стало гуманістичне розуміння джерел розвитку особистості. Г. Балл, I. Бех, А. Бойко, І. Зязюн, В. Кремень, В. Рибалка, В. Ягупов та інші науковці акцентують увагу на гуманістичній парадигмі освіти і виховання, на необхідності забезпечення суб'єктності дитини в освітньо-виховному процесі. Поява нової особистісно-гуманістичної парадигми, своєю чергою, засвідчує прогресивні тенденції оновлення, реформування освіти відповідно до прогресивного поступу суспільства на певному етапі його розвитку.

У сучасних українських реаліях особливо гостро підсилюється актуальність забезпечення особистісного зростання дітей-сиріт в умовах трансформаційних змін. Їх інтеграція в соціум на паритетних засадах уможливлюється шляхом організації в системі інституційних закладів освіти ефективних форм опікунсько-виховної діяльності; потребують удосконалення методи, технології надання фахової допомоги та підтримки дітей, що залишилися без піклування батьків; постає проблема впровадження інноваційних підходів 3 метою надання професійної допомоги дітям-сиротам на основі науково обгрунтованих концепцій виховання. Дослідження проблеми виховання дітей-сиріт у контексті особистісної парадигми має важливе теоретичне й практичне значення для сучасної освіти України, оскільки допомагає усвідомити роль держаних закладів опіки у подальшому вдосконаленні системи суспільного виховання дітей 3 урахуванням реалій сьогодення, у вимірі нової парадигми освіти, на основі переосмислення іiі пріоритетів $\mathrm{i}$ цінностей, формування нових концептуально-методологічних підходів до освітньовиховної діяльності.

Аналіз останніх наукових досліджень. Теоретико-методологічні розвідки, що розкривають сучасні підходи до організації й удосконалення виховання дітей в умовах державних закладів опіки здійснено Л. Канішевською, О. Кузьміною, В. Покась, А. Поляничко, В. Слюсаренко, Н. Султановою, Ю. Яблоновською та ін. Проблеми суспільного виховання дітей-сиріт в інтернатних закладах та дитячих будинках розглядали такі дослідники, як: С. Бадер, Л. Волинець, І. Звєрєва, Н. Павлик, Л. Фуштей та ін. Автори вказують на суттєві недоліки такої форми життєвого устрою дітей-сиріт, наголошуючи, що виховання дітей-сиріт у таких закладах призводить до деформації процесу формування системи цінностей та ціннісних орієнтацій, ускладнень особистісного розвитку, емоційної та інтелектуальної сфери, що зумовлює специфіку виховання дітей. Зокрема, вчені зауважують недостатність врахування педагогами інтернатних закладів освіти особистісно орієнтованого підходу до виховання дітей-сиріт. Більшість дослідників поділяють думку про те, що державна система опіки та виховання дітей-сиріт потребує конструктивного реформування, диференціації й індивідуалізації щодо підходу до потреб і вимог дитини та наголошують на актуальності забезпечення особистісного зростання дітей в умовах трансформаційних змін й оновлених форм державної опіки.

Провідні положення особистісно орієнтованої освітньої парадигми обгрунтовано в студіях відомих психологів та педагогів, зокрема: В. Андрущенка, Ш. Амонашвілі, І. Беха, А. Бойко, Є. Бондаревської, О. Дубасенюк, І. Зязюна, Л. Качалової, К. Якиманської та ін. Основними функціями сучасної особистісно орієнтованої освіти $\epsilon: 1)$ створення умов для саморозвитку й розкриття різних потенцій особистості; 2) культивування різних форм активності педагога та дитини; 3) реалізація стратегії підтримки та поваги до дитини; 4) створення умов вільного вибору сфер залучення до соціокультурних цінностей. Особистісно 
орієнтована парадигма виховання виступає своєрідним методологічним імперативом, що відповідає потребам розвитку i самореалізації духовного начала людини в новій соціокультурній ситуації (Дубасенюк, 2012). В центрі особистісно орієнтованої педагогіки стає особистість дитини, ії самобутність, самоцінність. Особистісно орієнтоване виховання, на думку I. Беха, - це виховання в дитини переживань стосовно світу людей і світу природи, тому що тільки те, що емоційно пережите особистістю, стає іiі ціннісно-смисловим надбанням. Переживаючи смисли життєвих явищ, дитина освоює соціокультурний світ. У просторі переживань і відбувається саморозвиток і самовизначення людини як особистості (Бех, 2003, с. 14).

Крізь призму педагогічної підтримки особистісно орієнтований підхід розглядає Л. Качалова та підкреслює, що в його основі лежать процеси, спрямовані на розкриття особистісного потенціалу і створення умов для самоактуалізації особистості (Качалова, 2007 , с. 65).

3 позиції А. Бойко, в основі особистісного підходу до виховання лежить суб'єктсуб'єктна взаємодія, доцільні гуманні стосунки дитини й педагога, які є рівноправними партнерами у спілкуванні, прислуховуються один до одного, узгоджують свої позиції (Бойко, 2001, с.8).

Аналіз наведених дефініцій дає підстави вважати, що категорія особистісного підходу до виховання не має однозначних тлумачень, відтак й єдиного погляду на виховання дітейсиріт у контексті особистісної парадигми, що зумовлює потребу перегляду іiі основних теоретико-методологічних положень з урахуванням специфіки соціальних умов виховання в державних закладах опіки.

Мета статті - обгрунтувати теоретико-методологічні основи виховання дітей-сиріт у контексті особистісної парадигми. Аналіз особистісного, особистісно-діяльнісного, гуманістичного, суб'єктного, синергетичного методологічних підходів до організації виховання дітей-сиріт у контексті особистісної парадигми.

Виклад основного матеріалу дослідження. Розвиток та виховання особистості дитини у контексті особистісної парадигми передбачає надання їй допомоги у виробленні певної життєвої стратегії, тобто «моделі побудови й здійснення особистістю свого життя 3 урахуванням перспективи, в якій втілюються ключові цілі особистості, суперечності між суспільними та ії особистими цілями, а також між цілями та реальними можливостями їх здійснення» (Сазоненко, 2000). Поняття «виховання» все більше набуває значення життєтворчості, зразки і норми культурного, гідного життя втілені в цінностях виховання. Виховання розглядається як процес самоорганізації особистості засобами своїх внутрішніх ресурсів, що потребують певної зовнішньої ініціації, створення оптимальних суспільних умов, освітнього середовища, в якому виховується дитина (Доній, Несен, Сохань, Срмакова, 1996).

Зауважимо, що виховання дітей-сиріт у контексті особистісної парадигми грунтується на основі не одного, а декількох підходів. Доповнюючи один одного, вони разом визначають стратегію виховання й детермінують тактику дій педагога у конкретній ситуації й у певний проміжок часу. Виховання дітей-сиріт у контексті особистісної парадигми повинно опиратися, на наш погляд, на особистісний, суб'єкт-суб'єктний, гуманістичний, синергетичний підходи. Вважаємо за необхідне детально проаналізувати сутність кожного 3 них.

Особистісний підхід передбачає допомогу вихованцю в усвідомленні себе особистістю, у виявленні, розкритті своїх можливостей, становленні самосвідомості, в здійсненні особистісно значущих i суспільно прийнятних самовизначень, самореалізації, 
самоутвердження. Особистісний підхід ми розглядаємо, як важливий психологопедагогічний принцип, основу якого складає сукупність вихідних теоретичних положень про особистість та практичних методичних засобів, що сприяють ії цілісному розумінню, вивченню та гармонійному розвитку (Пехота, 2003). Це певний методологічний інструментарій, що спирається на синтез видобутих психологічною та педагогічною наукою закономірностей побудови, функціонування та розвитку особистості.

Значний інтерес представляє концепція В. Рибалки, згідно якої для реалізації особистісного підходу обов'язковими $є$ організація виховної роботи на цілісному, системному уявленні про особистість; розробка та використання особистісно орієнтованого комплексу методів вивчення, стимуляції, розвитку та реалізації особистості; опора на цілісне уявлення про життєвий шлях особистості, охоплення найбільш важливих, довготривалих, ключових періодів ії становлення; забезпечення виявлення особливостей індивіда, яке б давало змогу прогнозувати, попереджати й розв'язувати його особистісні проблеми, надавати йому (в разі необхідності) адекватну допомогу (Рибалка, 2002, с. 81).

Особистісно орієнтований підхід, за I. Бехом «..є своєрідним методологічним інструментарієм, основу якого становлять сукупність вихідних концептуальних уявлень, цільових установок, методика психодіагностичних та психолого-технологічних засобів, що забезпечують більш глибоке, цілісне розуміння пізнання особистості, іiі розвиток» (Бех, 2003 , с.17). Основу особистісно-оріснтованого підходу складають пізнання особистості дитини, глибоке цілісне розуміння іії та гармонійний розвиток.

Окреслимо основні завдання щодо врахування й застосування особистісноорієнтованого підходу до виховання дітей-сиріт у контексті особистісної парадигми а саме: розробка соціально-педагогічних технологій виховання дитини-сироти у процесі іiі самовизначення, самореалізації та самоствердження; підбір змісту, форм та методів особистісного розвитку дитини-сироти; орієнтація змісту виховного процесу на особистісний розвиток дитини, яка перебуває в державному закладі опіки; реалізація принципу свободи особистості дитини в сенсі вибору нею пріоритетів, освітніх «маршрутів»; необхідність цілеспрямованого проєктування варіативного виховного середовища, що забезпечує індивідуальні траєкторії розвитку дітей-сиріт.

Результат застосування особистісно орієнтованого підходу у вихованні дітей сиріт, на наш погляд, полягають у виявленні внутрішнього потенціалу вихованців, їх самореалізації, саморозвитку, адаптації в соціумі. Система виховання буде реально особистісною настільки, наскільки вона працюватиме на особистісний розвиток кожної дитини-сироти.

Таким чином, виховання дітей-сиріт, що грунтується на особистісному підході, реалізується через діяльність, метою якої $\epsilon$ саморозвиток дітей-сиріт, розкриття їх внутрішнього потенціалу.

Гуманістичний підхід до організації виховання - це сучасна науково-практична освітня стратегія, в центрі якої стоїть конкретна дитина, їі можливості, індивід і творче самовираження. За такої стратегії виховний процес стає простором повноцінного життя, інструментом вирішення життєвих проблем і особистісного зростання (Звєрєва, 2013, с. 33). Опора на позитивне в дитинісироті, на ії здатність до розвитку, повага до ії прав, довіра і конфіденційність у співпраці 3 вихованцем - принципи реалізації цього підходу у вихованні дітей-сиріт у контексті особистісної парадигми. Вибудовуючи педагогічну діяльність, беручи до уваги базові потреби особистості, вихователь має уважно відслідковувати зміни, що відбуваються в особистісних якостях дитини-сироти: спрямованість ціннісних орієнтацій, життєвих планів, поведінка, та оперативно коригувати процес виховання, орієнтуючи його на задоволення особистісних потреб дітей цієї категорії. 
Гуманістичний підхід грунтується на розумінні, визнанні та прийнятті вихованця. Ці ж самі компоненти повинні бути введені в структуру відносин дитини 3 педагогом. Дитинасирота стикається 3 проблемами розуміння, визнання і сприйняття свого вихователя. Накладені один на одного, ці системи створюють складну структуру педагогічних стосунків (Сазоненко, 2000, с. 59).

Розуміння - проникнення у внутрішній світ вихованця, що відбувається за допомогою почуття та логіки. Велике значення щодо розуміння дитини-сироти має взаємна відвертість між нею та педагогом, що передбачає необхідність відкритого вираження почуттів кожним iз них, здатність розуміти дитину. Відкритість зумовлюється здатністю педагога не тільки «постати перед дитиною в ореолі знань, досвіду, впевненості, а й показати свої сумніви, допомогти вихованцю зрозуміти, що труднощі та помилки бувають у всіх людей». Тільки в такому випадку у дитини-сироти «народжується реальна надія на успіх, зникає страх перед майбутнім» (Канішевська, 2011, с. 59-60).

На думку Л. Канішевської, важливим аспектом гуманізації виховного процесу є прийняття вихованця - добросердне ставлення до нього без урахування результатів його діяльності, незалежно від помилок та прорахунків у поведінці, що грунтується на вимогливості та принциповості на фоні позитивного ставлення, бажанні допомогти. Прийняття дитини-сироти визначає важливий шлях у вихованні - зміцнення психологічної позиції в соціумі, іiі самопочуття. Емпатійне прийняття вихованця, зумовлює розвиток головної життєвої сили - його руху вперед (Канішевська, 2011, с. 59-60). Емпатійне прийняття дитини-сироти передбачає: використання спеціальних прийомів демонстрації прийняття вихованця: «пильна увага», «контакт очей», «емпатійне слухання»; відкритість спілкування, конфіденційність розмов із вихованцем; відмову від висловлювання обурення, невіри, надання натомість переваги намаганням увійти в стан вихованця й зрозуміти причини його вчинку, проаналізувати їх, і тільки після цього серйозно обговорити 3 ним його негативні дії (Канішевська, 2011, с. 102).

Гуманістичний підхід до виховання дітей-сиріт у контексті особистісної парадигми, крім безоціночного прийняття дитини, має також покладатися на любов до неї, що проявляється у дбайливому, співчутливому ставленні, відповідальності за ії життя, здоров'я і майбутнє. «Любов тим потрібніша вихованцеві, чим слабші його успіхи, чим важче йому долати проблеми. Тому педагог має знайти в своїй душі співчуття, теплоту і сердечні слова. Адже впевненість вихованця у любові вихователя - головний резерв у вихованні. Любов, яка пов'язує вихователя й вихованця як джерело природної свободи мислення, почуттєвості, поведінки останнього, його готовності до поміркованих рішень, та відповідальність за вихованця протягом дорослішання - провідні характеристики успішної педагогічної діяльності (Куторжевська, 2004, с. 89).

Реалізація гуманістичного підходу у вихованні дітей-сиріт у контексті особистісної парадигми має передбачати дотримання педагогами таких правил: ставитися до вихованця як до найвищої цінності; допомагати дитині зрозуміти індивідуальну цінність через відчуття любові, поваги, довіри, розвиток у неї почуття гідності за себе; виявляти любов і турботу до вихованця; разом 3 дитиною вирішувати іiі життєві проблеми, розвивати у вихованця здібності конструювати соціально схвалювану діяльність; уникати навішування ображаючих ярликів; бути щедрими на заохочення, скупими на осудження; спонукати дитину до роботи над собою і не зловживати методами жорстокого викорінення недоліків; частіше надавати вихованцю можливість самостійно конструювати власну діяльність, стосунки 3 іншими; бути для дитини джерелом соціального досвіду, фахівцем, який є цікавим для неї, якого вона поважає. 
Таким чином, гуманістичний принцип особистісної парадигми виховання дітей-сиріт змінює підходи в організації виховання та потребує глибоко розуміння перш за все психологічних особливостей особистості дитини, добирати нові способи педагогічної взаємодії. Одним з вихідних положень даної парадигми є однозначне розуміння дитинисироти як суб'єкта та мети виховання. Тому, з огляду на це, виховання - це не «вплив» на особистість, а створення оптимальних умов для самопізнання, самореалізації на рівні партнерства та співтворчості дитини та вихователя (Бойко, 2001, с. 9). При цьому потрібно врахувати, що тільки суб'єкт-педагог здатний сформувати суб'єкта-вихованця.

Відтак із позиції суб'єктного підходу, виховання дітей-сиріт у контексті особистісної парадигми здійснюється як процес суб'єкт-суб'єктної взаємодії, що грунтується на діалозі, обміні змістами, співробітництві їі учасників. Зміст спільної діяльності не регламентується, має відкритий характер і стає особистісно зорієнтованим. Дитина-сирота приймає активну участь у конструюванні змісту виховання, потрібного їй для самотворення власної долі, включається у життєтворчість. Суб'єктність дитини-сироти розглядається як характеристика особистості, що відображає не лише ії активність, але й вибірковість, активно-відповідальне перетворення ставлення до самої себе та оточення, діяльності, життя загалом. Тому важливим у вихованні дітей-сиріт у контексті особистісної парадигми $\epsilon$ врахування основ особистісно-діяльнісного підходу, які були закладені у роботах Б. Ананьєва, Л. Виготського, О. Леонтьєва, С. Рубінштейна, К. Ушинського, де особистість розглядається як суб'єкт діяльності, яка сама, формуючись у діяльності й у спілкуванні 3 іншими людьми, визначає характер цієї діяльності та спілкування. Вітчизняні науковці О. Пєхота, В. Семиченко акцентують увагу на доцільності реалізації особистіснодіяльнісного підходу в освітньо-виховній діяльності, яка своїм внутрішнім змістом передбачає співробітництво, саморозвиток суб'єктів освітньо-виховного процесу, виявлення їх особистісних функцій (Пєхота, 2003). Поєднання особистісного й діяльнісного аспектів є виключно важливим, бо саме у такий спосіб досягається необхідна цілісність образу педагога-новатора (Сластёнин В. А. и Подымова, 1997). Особистісно-діяльнісний підхід щодо виховання дітей-сиріт у контексті особистісної парадигми передбачає діяльність педагога (або інших суб'єктів опікунсько-виховної діяльності) як активну взаємодію з вихованцями, через яку досягаються цілі педагогічної діяльності, що регулюють активність зазначеної категорії дітей, враховують їхні потреби, а вихователеві дозволяють відбирати зміст, форми і методи роботи (Горілий, 2001). Це означає також, що необхідним $\epsilon$ обов'язкове включення дітей-сиріт у діяльність із розв'язанням їхніх проблем, що сприятиме їхньому благополуччю, особистісному розвитку. Етапами такої роботи $\epsilon$ організація вихованців щодо усвідомлення ними своїх проблем, мотивація їх до розв'язання цих проблем у співпраці з педагогом, усвідомлення дітьми-сиротами мети такої співпраці, вибір засобів досягнення мети, здійснення діяльності щодо розв'язання проблем і набуття в цій діяльності нового досвіду, якостей, властивостей, співставлення результату з метою, надання оцінки взаємодії з вихователем, корекція співпраці з ним в діяльності і спілкуванні. Слід звернути увагу на необхідність залучення вихованців до участі саме в соціально схвалюваних видах діяльності, серед яких: навчальна, проєктна, суспільно-корисна, природоохоронна, спортивна, краєзнавча, управлінська і т.д. Важливим також є дотримання дітьми-сиротами свободи вибору змісту й форм педагогічної діяльності, добровільності участі кожного в загальній справі (Волкова, 2008, с.42).

Розглянемо синергетичний підхід до виховання дітей-сиріт у контексті особистісної парадигми. Виховний процес з погляду синергетичного підходу розглядається як поліхронічна цілісність, система виховних відносин, персоналізована єдність двох 
взаємозалежних виховних впливів: «вихователь - вихованець», «вихованець - вихователь», коеволюційна діяльність. У цьому разі статус вихователя й вихованця у контексті виховної взаємодії підвищується до рівня партнерства, що виявляється у співробітництві та співтворчості, а відтак виступає одним із найважливіших чинників ефективності особистісно-гуманістичного педагогічного процесу. Вихованець, маючи статус повноцінного суб'єкта виховної діяльності - партнера виховної взаємодії, потребує не директив (настанов, рекомендацій, наказів), а, перш за все, допомоги й підтримки, що грунтуються на синергетичному поєднанні педагогічної вимогливості й особистісної поваги. Звідси і своєрідна позиція педагога у виховному процесі - позиція «поряд»: $з$ одного боку, він - організатор виховуючого середовища, дослідник, спостерігач, з іншого - друг, помічник, порадник і наставник у розвитку особистості вихованця. Успішна реалізація професійної діяльності вихователя безпосередньо залежить від оптимального виявлення особистісного смислу діяльності і поведінки вихованця для побудови синергетичної конфігурації подальшої виховувальної взаємодії (Бойко, 2003).

Висновки та перспективи подальших розвідок. Здійснивши аналіз наукових напрацювань вчених з означеного питання можемо констатувати, що особистісна парадигма виховання дітей-сиріт не просто декларує, а утверджує дитину як найвищу цінність життя, передбачає визнання іiі індивідуальності, самобутності, самоцінності. Вихованець розглядається як особистість, яка сама може вибирати такий шлях освіти, який допоможе їй досягнути найкращих результатів.

Особистісна парадигма виховання дітей-сиріт передбачає суб'єкт-суб'єктні відносини дитини та педагога. Сутнісною основою виховання, виступають особистість дитини, орієнтація педагога на гуманні, демократичні принципи спільної 3 дитиною життєдіяльності, розуміння дитини-сироти як суб'єкта і мети виховання, усвідомлення виховання як соціально-особистісного феномена, досягнення єдності у формуванні особистості природного й соціального чинників, організація «саморуху» від нижчих до вищих ступенів розвитку та самодіяльності.

Гуманістична стратегія виховання дітей-сиріт у контексті особистісної парадигми визначає гуманістичне навантаження технологічних засобів іiі реалізації, характерними ознаками яких є педагогічна допомога і підтримка; соціальний захист; діалогічність, творчопошуковий характер, поєднання традиційності й інноваційності, гнучкий контроль i самоконтроль. Вибудовуючи власну діяльність згідно 3 особистісно-гуманістичною стратегією парадигми виховання дітей-сиріт, педагог займає позицію наставника, друга $\mathrm{i}$ помічника вихованця. Саме така позиція в ідеалі повинна стати синергетичною аксіомою виховної діяльності педагога нової генерації, що стає можливим за умови сходження від мети і завдань особистісної парадигми виховання - через іiі сутність і функції безпосередньо до стратегії й технології педагогічної підтримки, допомоги й захисту дитинисироти, актуалізації іï особистісних ресурсів. Перспективи подальших наукових розвідок вбачаємо у розгляді особливостей застосування технологій актуалізації особистісного ресурсу дітей-сиріт в контексті особистісної парадигми.

\section{СПИСОК ВИКОРИСТАНИХ ДЖЕРЕЛ}

Професійна педагогічна освіта: особистісно орієнтований підхід (2012): монографія [за ред. О. Дубасенюк]. Житомир: Вид-во ЖДУ ім. І. Франка. 436 с.

Качалова, Л., Качалов, Д. та Качалов, А. (2007). Личностно-ориентированный подход в образовании: педагогіка личности. Пособие к спецк. Шадринск: Изд-во «Шадринский дом печати». $82 \mathrm{c.}$ 
Бойко, А. (2001). Парадигмальні напрями виховання: варіанти вибору. Рідна школа. № 3. c. $7-10$.

Психологія $і$ педагогіка життєтворчості (1996): навч.-метод. посібник [ред. рада: В. Доній (голова), Г. Несен (заст. голови), Л. Сохань, І. Срмаков (наук. ред.) та ін.]. Київ. 792 c.

Підготовка майбутнього вчителя до впровадження педагогічних технологій (2003): навчальний посібник [О. Пєхота, В. Будак, А. Старева, К. Нор, В. Шуляр, І. Михайлицька, I. Манькусь; за ред. І. Зязюна, О. Пехоти]. К.: Видавництво А.С.К. 240 с.

Рибалка, В. (2002). Особистісний підхід як психолого-педагогічний принцип організації профільної та професійної підготовки учнівської молоді. Психологія особистісно орієнтованої професійної підготовки учнівської молоді: науково-методичний посібник. Київ-Тернопіль: Підручники і посібники. с. 80-90.

Бех, І. (2003). Виховання особистості: у 2 кн. Київ: Либідь. Кн. 1. Особистісно орієнтований підхід: теоретико-технологічні засади. 280 с.

Енциклопедія для фахівців соціальної сфери (2012). 2-ге видання [за заг. ред. проф. I. Звєрєвої]. Київ, Сімферополь: Універсум. 536 с.

Перспективні освітні технологї (2000): науково-метод. посібник [А. Алексюк, І. Бех, Т. Демків та ін.; заг. ред. Г. Сазоненко]. Київ: Гопак. 560 с.

Канішевська, Л. (2011). Теоретико-методологічні засади виховання сочіальної зрілості старшокласників шкіл-інтернатів для дітей-сиріт та дітей, позбавлених батьківськой опіки, у позаурочній діяльності. Доктор педагогічних наук. Інститут проблем виховання НАПН України.

Горілий, А. (2004). Історія соиіальної роботи. Навчальний посібник. Тернопіль: Видавництво Астон. 174 с.

Волкова, В. (2008). Формування готовності до сімейного життя у дітей-сиріт у діяльності практичного психолога. Практична психологія та соиіальна робота. № 6. с. 40-48.

\section{REFERENCES}

Profesiina pedahohichna osvita: osobystisno oriientovanyi pidkhid (2012) [Professional Pedagogical Education: a Personality-oriented Approach]: monohrafiia [za red. O. Dubaseniuk]. Zhytomyr: Vyd-vo ZhDUim. I. Franka. 436 s. (in Ukrainian)

Kachalova,L.,Kachalov, D. \& Kachalov, A. (2007). Lichnostno-oriyentirovannyy podkhod v obrazovanii: pedagogika lichnosti [Personality-oriented Approach in Education: Pedagogy of Personality]. Posobiye k spetsk. Shadrinsk: Izd-vo "Shadrinskiy dompechati”. 82 s. (in Russian)

Boiko, A. (2001). Paradyhmalni napriamy vykhovannia: varianty vyboru [Paradigmatic Directions in Education: Options of Choice]. Ridna shkola. No 3. s. 7-10. (in Ukrainian)

Psykholohiia $i$ pedahohika zhyttietvorchosti (1996) [Psychology and Pedagogy of Life Creation]: navch.-metod. posibnyk [red. rada: V. Donii (holova), H. Nesen (zast. holovy), L. Sokhan, I. Yermakov (nauk. red.) tain.]. Kyiv. 792 s. (in Ukrainian)

Pidhotovka maibutnoho vchytelia do vprovadzhennia pedahohichnykh tekhnolohii (2003) [Future Teachers' Training for the Implementation of Pedagogical Technologies]: navchalnyi posibnyk [O. Piekhota, V. Budak, A. Stareva, K. Nor, V. Shuliar, I. Mykhailytska, I. Mankus; zared. I. Ziaziuna, O. Piekhoty]. Kyiv.: Vydavnytstvo A.S.K. 240 s. (inUkrainian)

Rybalka, V. (2002). Osobystisnyi pidkhid yak psykholoho-pedahohichnyi pryntsyp orhanizatsii profilnoi ta profesiinoi pidhotovky uchnivskoi molodi [Personality Approach as Psychological and Pedagogical Principle of Organization of Profile and Professional Training of Student Youth]. 
Psykholohiia osobystisno oriientovanoi profesiinoi pidhotovky uchnivskoi molodi: naukovometodychnyi posibnyk. Kyiv-Ternopil: Pidruchnyky i posibnyky. s. 80-90. (inUkrainian)

Bekh, I. (2003). Vykhovannia osobystosti [Education of Personality]: u 2 kn. Kyiv: Lybid. Kn. 1. Osobystisno oriientovanyi pidkhid: teoretyko-tekhnolohichni zasady. $280 \mathrm{~s}$. (inUkrainian)

Entsyklopediia dlia fakhivtsiv sotsialnoi sfery (2012) [Encyclopedia for Social Professionals]. 2-he vydannia [zazah. red. prof. I. Zvierievoi]. Kyiv, Simferopol: Universum. 536 s. (inUkrainian)

Perspektyvni osvitni tekhnolohii (2000) [Advanced Educational Technologies]: naukovometod. posibnyk [A. Aleksiuk, I. Bekh, T. Demkivtain.; zah. red. H. Sazonenko]. Kyiv: Hopak. 560 s. (in Ukrainian)

Kanishevska, L. (2011). Teoretyko-metodolohichni zasady vykhovannia sotsialnoi zrilosti starshoklasnykiv shkil-internativ dlia ditei-syrit ta ditei, pozbavlenykh batkivskoi opiky, $u$ pozaurochnii diialnosti [Theoretical and Methodological Bases of Upbringing of Social Maturity of Senior Students at Boarding Schools for Orphans and Children Deprived of Parental Care in Extracurricular Activities]. Doktor pedahohichnykh nauk. Instytut problem vykhovannia NAPN Ukrainy. (in Ukrainian)

Horilyi, A. (2004). Istoriia Sotsialnoi Roboty [History of Social Work]. Navchalnyi posibnyk. Ternopil: Vydavnytstvo Aston. 174 s. (in Ukrainian)

Volkova, V. (2008). Formuvannia hotovnosti do simeinoho zhyttia u ditei-syrit u diialnosti praktychnoho psykholoha [Formation of Orphans' Readiness for Family Life in the Activities of a Practical Psychologist]. Praktychn apsykholohiia ta sotsialna robota. No 6. s. 40-48. (in Ukrainian)

\title{
THEORETICAL AND METHODICAL APPROACHES TO THE UPBRINGING OF CHILDREN-ORPHANS IN THE CONTEXT OF PERSONALITY PARADIGMS
}

\author{
Halyna Lialiuk \\ $\mathrm{PhD}$ (Psychology), Associate Professor, \\ Associate Professor at the Department of Psychology of \\ Activities in Special Conditions, \\ Lviv State University of Internal Affairs, \\ Lviv, Ukraine \\ ORCID: 0000-0002-4819-6247 \\ e-mail: gala_psycholog@ukr.net
}

\begin{abstract}
The article deals with the problem of raising orphans in state institutions of guardianship. It is noted that in modern Ukrainian realities, the relevance of ensuring the personal growth of orphans in the conditions of transformational changes is particularly important today. The theoretical and methodical foundations of the education of orphans in the context of the personal paradigm are substantiated. The article analyzes the personality, personality-activity, humanistic, subjective, synergetic approaches to the organization of orphans' upbringing in the context of the personality paradigm.

The personality paradigm of orphans' upbringing does not just declare, but affirms the child as the highest value of life, involves the recognition of child's individuality, originality, and selfworth. The pupil is regarded as a person who can choose such a path of education that will help $\mathrm{him} / \mathrm{her}$ achieve better results. Personality paradigm of orphans'upbringing involves the subjectsubject relationship of the child and the teacher. The essential basis of upbringing is the child's personality, recognition of a child's personality as the highest value, the teacher's orientation to the
\end{abstract}


humane, democratic principles of life shared with the child, understanding the child as a subject and the purpose of upbringing, awareness of upbringing as a social and personal phenomenon.

The humanistic strategy of orphans' upbringing in the context of the personality paradigm determines the humanistic load of technological means of its implementation, the characteristic features of which are pedagogical assistance and support; empathic attitude towards the child; dialog, creative and exploratory character, combination of traditions and innovations, flexible control and self-control.

Key words: children-orphans, personality paradigm of upbringing, personality approach, personality-activity approach, humanistic approach, subject-subject approach, synergetic approach.

Стаття надійшла до редакиії 07. 05. 2020 р. 